\title{
IDENTIFIKASI KECACATAN COIL BASAH DAN UPAYA PERBAIKAN DENGAN METODE SEVEN TOOLS DAN FAULURE MODE AND EFFECT ANALYSIS (FMEA) DI PT. XYZ MEDAN
}

\author{
Tiara Melinda ${ }^{1}$, Elisabeth Ginting ${ }^{2}$ \\ Mahasiswa Departemen Teknik Industri, Fakultas Teknik USU ${ }^{1}$ \\ Staf Pengajar Departemen Teknik Industri, Fakultas Teknik USU ${ }^{2}$
}

\begin{abstract}
Abstrak : PT. XYZ merupakan perusahaan yang bergerak dibidang insektisida dengan produk obat nyamuk bakar (coil). PT. XYZ melakukan proses produksi sesuai dengan Standard Operating Procedure (SOP) yang telah ditetapkan, namun pada kenyataanya masih ditemukan produk yang tidak sesuai dengan spesifikasi yang diinginkan perusahaan (cacat). Identifikasi kecacatan coil basah dilakukan dengan menerapkan metode Seven Tools. Hasil penelitian menunjukkan terdapat tiga jenis kecacatan yang terjadi yaitu coil terpotong sebanyak $4757 d c$, coil retak sebanyak $3307 d c$ dan coil renggang sebanyak $2375 d c$. Faktor penyebab kecacatan umumnya dipengaruhi viskositas tepung onggok yang berperan sebagai perekat adonan coil. Hasil control chart menunjukkan jumlah produk cacat yang berada diluarcontrol yaitu sebesar71,43\%. Hasilbrainstormingyang dirincikan pada cause and effect diagram, didapat beberapa faktor yang menyebabkan tingginya kecacatan yaitu faktor manusia dan mesin. Langkah selanjutnya adalah menetapkan faktor penyebab kecacatan dengan metode FMEA. Jenis kecacatan terpotong memiliki nilai RPN tertinggi pada faktor manusia yang kurang inisiatif sebesar 240.Jenis kecacatan retak memiliki nilai RPN tertinggi pada faktor mould bermasalah sebesar 256 .
\end{abstract}

Kata Kunci: Kualitas, Seven tools,Failure Mode and Effect Analysis (FMEA)

\begin{abstract}
Abstrack : PT. XYZ is a company engaged in insecticide with insect repellent product fuels (coil). PT.XYZ doing production process in accordance with Standard Operating Procedure (SOP) that has been set, but in fact still found a product that doesn" $t$ comply with the specifications of the desired company (reject). Identification of disability wet coil performed by applying the Seven Tools method. The result showed there were three types of dissability that occurs, coil is cut off as much as 4.757 dc, coil cracks as much as 3.307 dc and coil rift as much as 2.375 dc. Factors the causes of disability are generally influenced by the viscocity onggok fluor as gluten coil dough. The result of the control chart show the number of product defect which are outside the control of $71,43 \%$. The result of the brainstorming to make a cause and effect diagram, obtained some of the factor of disability that is factor of human and machine. The next step is to assign a cause factor of disability with FMEA. Type of disability a truncated value is the highest RPN on human factor of less initiative amounting 240. The type of disability of the highest RPN has cracked on the problematic mould factor of 256.
\end{abstract}

Keywords: Quality, Seven Tools, Failure Mode and Effect Analysis (FMEA) 


\section{PENDAHULUAN}

Pengendalian kualitas pada perusahaan manufaktur ataupun jasa sangatlah diperlukan. Perusahaan harus dapat menjaga kualitas produk yang dihasilkannya agar dapat diterima oleh kosumen.Pengendalian kualitas dibutuhkan untuk meminimalisir adanya produk yang cacat agar perusahaan tidak mengalami kerugian, baik dari segi waktu yang terbuang untuk proses produksi ataupun dari segi keuangan.

PT. XYZ merupakan suatu perusahaan yang bergerak di bidang pembuatan obat nyamuk bakar (coil) dan sampai sekarang merupakan salah satu perusahaan ternama di Indonesia. Kecacatan yang terjadi pada produk obat nyamuk bakar (coil) adalah terpotong, retak dan renggang. Perusahaan menetapkan batas toleransi kecacatan yaitu sebesar $15 \%$, namun pada kenyataan di lapangan persentase kecacatan yang terjadi melebihi batas toleransi yang ditetapkan perusahaan. Perusahaan harus mengeluarkan biaya tambahan untuk proses daur ulang produk cacat tersebut.

Upaya perbaikan dapat dilakukan dengan mengidentifikasi kecacatan produk obat nyamuk bakar (coil) sehingga dapat membantu pengambilan keputusan untuk meminimalisir kecacatan yang terjadi.Oleh karena itu perlu dilakukan penelitian untuk mengidentifikasi sumber-sumber penyebab kecacatan pada coil basah tersebut dengan metode Seven Tools dan FMEA (Failure Mode andEffect Analysis).

\section{POKOK PERMASALAHAN}

Berdasarkan latar belakang diatas, banyaknya coil yang cacat melebihi standar perusahaan yaitu $15 \%$. Besarnya produk yang cacat menjadi masalah kualitas produk yang harus diatasi oleh karena itu perlu dilakukan identifikasi penyebab kecacatan coil basah di PT.SC Johnson Manufacturing Medan untuk meningkatkan kualitas produk.

\section{METODOLOGI}

\subsection{Metode Penelitian}

Metode yang dipakai dalam penelitian ini adalah metode penelitian deskriptif. Data-data yang digunakan diperoleh dari pengamatan langsun di lapangan, wawancara dan brainstorming dengan beberapa operator yang terkait proses produksi.

\subsection{Objek Penelitian}

Objek penelitian adalah coil basah dari PT. XYZ yang tidak sesuai dengan spesifikasi perusahaan.

\subsection{Identifikasi Masalah}

Masalah yang ditemui akan diidentifikasi untuk selanjutnya akan dicari penyelesaiannya. Secara umum tahapan-tahapan yang akan dilakukan dalam penelitian ini adalah :
1. Identifikasi dan perumusan masalah

2. Penetapan tujuan penelitian

3. Studi kepustakaan

4. Penentuan metode penyelesaian penelitian

\subsubsection{Identifikasi dan Perumusan Masalah}

Identifikasi dapat dilakukan dengan melakukan pengamatan secara langsung terhadap keadaan yang terjadi dilapangan. Perlunya dilakukan pengendalian kualitas dimaksudkan agar perusahaan secara kontinu dapat melakukan pengendalian produk secara terstruktur, sehingga hasil yang diperoleh dapat ditindaklanjuti.

\subsubsection{Tujuan Penelitian}

Tujuan dari penelitian ini adalah :

1. Mengidentifikasi kecacatan pada coil basah serta melihat kecacatan yang paling dominan pada coil basah

2. Mengurangi jumlah cacat coilbasah dengan mengidentifikasi faktor-faktor yang menjadi sumber kecacatan pada di PT. XYZ dan memberikan solusi berupa kontrol yang harus dilakukan.

\subsubsection{Studi Kepustakaan}

\section{A. Pengendalian Kualitas}

Pengendalian kualitas merupakan suatu sistem verifikasi dan penjagaan/ perawatan dari suatu tingkat kualitas produk atau proses yang dikehendaki dengan perencanaan yang seksama, pemakaian peralatan yang sesuai, inspeksi yang terus menerus serta tindakan korektif bilamana diperlukan. Jadi, pengendalian kualitas tidak hanya kegiatan inspeksi ataupun menentukan apakah produk itu baik (accept) atau jelek (reject).

\section{B. Pengendalian Kualitas dengan Seven Tools}

Konsep seven tools berasal dari Kaoru Ishikawa, ahli kualitas ternama dari Jepang. Menurut Ishikawa, 955 permasalahan kualitas dapat diselesaikan dengan seven tools. Untik memecahkan masalah sebaiknya dimulai dengan menggunakan pareto diagram dan cause-effect diagram sebelum mencoba menggunakan alat yang lain. Langkah-langkah dalam Seven tools adalah :

1) Stratification

2) Check Sheet

3) Histogram

4) Pareto Diagram

5) Scatter Diagram

6) Control Chart (Peta Kontrol)

7) Cause and Effect Diagram

C. FMEA (Failure Mode and Effect Analysis)

Failure Mode and Effect Analysis(FMEA) merupakan proses yang sistematis untuk mengidentifikasi potensi kegagalan yang akan timbul dalam proses dengan tujuan untuk 
mengeliminasi atau meminimalkan resiko kegagalan produksi yang akan timbul.

\section{1) Severity}

Severityadalah penilaian keseriusan efek modus potensi kegagalan yang meliputi komponen, sub-sistem, sistem atau pelanggan jika itu terjadi. Severityharus dinilai pada skala 1 sampai 10 , dengan 1 tidak ada dan 10 adalah paling parah.

\section{2) Occurence}

Occurence adalah kesempatan bahwa salah satu penyebab/mekanisme spesifik akan terjadi. Seperti kriteria severity, kemungkinan occurence didasarkan pada skala 1 sampai 10 , dengan 1 adalah setidaknya kemungkinan occurence dan 10 adalah tertinggi kemungkinan occurence.

\section{3) Detection}

Detection adalah penilaian kemungkinan bahwa proses kontrol yang diusulkan saat ini akan mendeteksi potensi kelemahan atau modus kegagalan berikutnya sebelum bagian atau komponen meninggalkan operasi manufaktur atau lokasi perakitan.

\section{4) Risk Priority Number (RPN)}

RPN adalah hasil peringkat dari severity (S), occurrence (O) dan detection (D), seperti dirumuskan :

$\mathrm{RPN}=(\mathrm{S}) \times(\mathrm{O}) \times(\mathrm{D})$

\section{PENGUMPULAN DAN PENGOLAHAN DATA}

\subsection{Pengumpulan Data}

Pengamatan dilakukan di area stamping tepatnya pada mesin coil master. Pada pengamatan yang dilakukan di lapangan, terdapat beberapa jenis kecacatan pada coil basah yaitu terpotong, retak dan renggang. Jumlah kecacatan coil basah diamati pada masing-masing mould (mould 1,2,3,4,5, dan 6) dari mesin coil master untuk setiap jenis kecacatan.

\subsection{Pengolahan Data}

\section{A. Stratifikasi}

Berdasarkan data yang diperoleh, stratifikasi yang ditetapkan pada kecacatan coil basah dapat dilihat pada Tabel 1.

Tabel 1. Stratifikasi Jenis Kecacatan pada Coil Basah

\begin{tabular}{cc}
\hline No & Jenis Kecacatan \\
\hline 1 & Terpotong \\
2 & Retak \\
3 & Renggang \\
\hline
\end{tabular}

\section{B. Check Sheet}

Pengamatan dilakukan dengan frekuensi sebanyak 21 kali. Check sheet kecacatan coil basah untuk masing-masing kecacatan pada masingmasing mould dapat dilihat pada Tabel 2.

Rekapitulasi jumlah kecacatan coil basah dari masing-masing mould untuk setiap jenis kecacatan dapat dilihat pada Tabel 2.

Tabel 2.Rekapitulasi Jumlah Kecacatan Coil Basah

\begin{tabular}{ccccccc}
\hline \multirow{2}{*}{ Jenis } & \multicolumn{7}{c}{ Jumlah Kecacatan } \\
\cline { 2 - 7 } Kecacatan & $\mathbf{1}$ & $\mathbf{2}$ & $\mathbf{3}$ & $\mathbf{4}$ & $\mathbf{5}$ & $\mathbf{6}$ \\
\hline Terpotong & 2.000 & 856 & 524 & 476 & 478 & 423 \\
Retak & 545 & 944 & 598 & 366 & 615 & 239 \\
Renggan & 581 & 345 & 280 & 274 & 724 & 171 \\
\hline
\end{tabular}

Rekapitulasi jumlah dari masing-masing jenis kecacatandapat dilihat pada Tabel 3.

\begin{tabular}{ccc} 
Tabel & $\begin{array}{c}\text { 3. Check } \\
\text { JumlahKecacatan Coil }\end{array}$ & $\begin{array}{c}\text { Sheet } \\
\text { Jumlah }\end{array}$ \\
\hline No. & Jenis Kecacatan & $\begin{array}{c}\text { Jumlan } \\
\text { Kecacatan } \\
\text { (DC) }\end{array}$ \\
\hline 1 & Terpotong & 4.757 \\
2 & Retak & 3.307 \\
3 & Renggang & 2.375 \\
\hline & Total & $\mathbf{1 0 . 4 3 9}$ \\
\hline
\end{tabular}

\section{Histogram}

Berdasarkan Tabel 3.dapat digambarkan histogram yang memperlihatkan jumlah kecacatan dari masing-masing jenis kecacatan. Histogram jumlah kecacatan dapat dilihat pada Gambar 1.

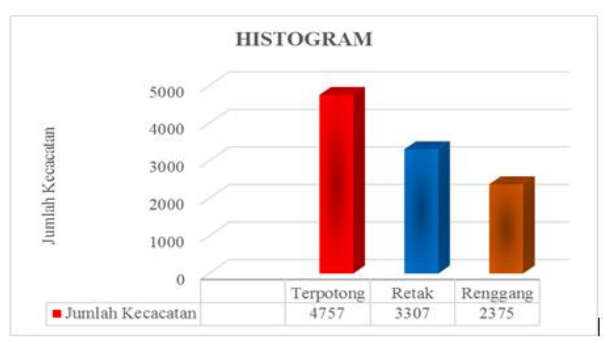

Gambar 1. Histogram Jumlah Kecacatan

Histogram menunjukkan bahwa jenis kecacatan terpotong memiliki kesalahan paling besar yaitu sebanyak 4.757 double coil, diikuti jenis kecacatan retak sebanyak 3.307 double coil dan jenis kecacatan renggang sebanyak 2.375 double coil.

\section{Pareto Diagram}

Aturan pareto yang digunakan pada penelitian ini adalah aturan pareto $80-20$ yang berarti $20 \%$ dari kecacatan produk menyebabkan $80 \%$ masalah pada proses produksi.

Pengurutan jumlah kesalahan dapat dilihat pada Tabel 4. 
Tabel 4. Pengurutan Jumlah Kecacatan

\begin{tabular}{cccc}
\hline $\begin{array}{c}\text { Jenis } \\
\text { Kecacatan }\end{array}$ & $\begin{array}{c}\text { Jumlah } \\
\text { Kecacatan } \\
\text { (DC) }\end{array}$ & $\begin{array}{c}\text { Persentase } \\
\text { Kecacatan }\end{array}$ & $\begin{array}{c}\text { Persentase } \\
\text { Kecacatan } \\
\text { Kumulatif } \\
(\boldsymbol{\%})\end{array}$ \\
\hline Terpotong & 4.757 & 45,57 & 45,57 \\
Retak & 3.307 & 31,68 & 77,25 \\
Renggang & 2.375 & 22,75 & 100 \\
\hline Jumlah & $\mathbf{1 0 . 4 3 9}$ & $\mathbf{1 0 0 , 0 0}$ & \\
\hline
\end{tabular}

Pareto diagramberdasarkan Tabel4. dapat dilihat pada Gambar 2.

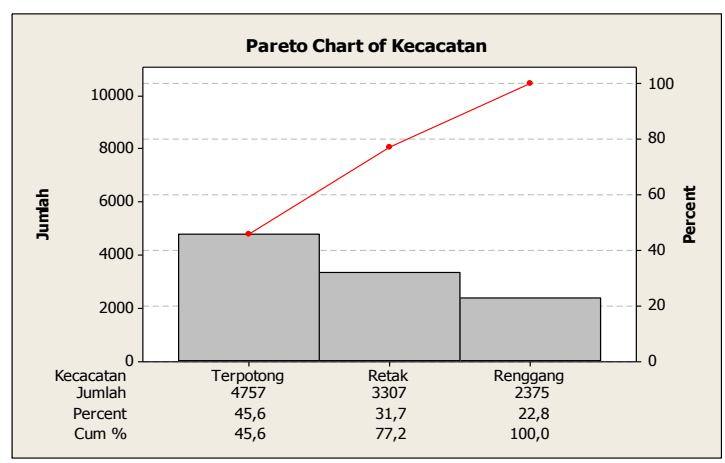

Gambar 2. Pareto Diagram

Menurut aturan pareto 80-20, dari Gambar 4. dapat diketahui bahwa terdapat dua jenis kecacatan yang memiliki persentase kecacatan kumulatif yang berada di bawah $80 \%$, yaitu terpotong dan retak. Kedua kecacatan tersebut selanjutnya perlu dilakukan identifikasi lebih lanjut.

\section{E. Scatter Diagram}

Kecacatan coil basah dapat diakibatkan oleh beberapa faktor, salah satu faktor yang berpengaruh adalah kualitas bahan terutama viskositas tepung onggok. Berikut ini merupakan scatter diagram dan perhitungan korelasi untuk setiap kecacatan yang persentase kesalahan kumulatifnya berada di bawah $80 \%$ (terpotong dengan retak) dengan viskositas tepung onggok.

Scatter diagram untuk kecacatan terpotong dengan viskositas tepung onggok dapat dilihat pada Gambar 3.

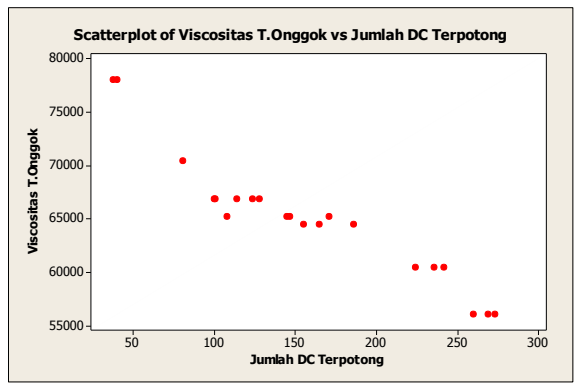

Gambar 3. Scatter Diagram untuk Terpotong dengan Viskositas Tepung Onggok

Nilai korelasi antara kecacatan terpotong dengan viskositas tepung onggok adalah sebagai berikut:

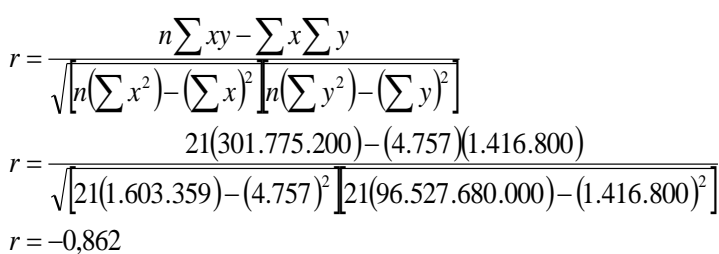

Scatter diagram untuk kecacatan retak dengan viskositas tepung onggok dapat dilihat pada Gambar 4.

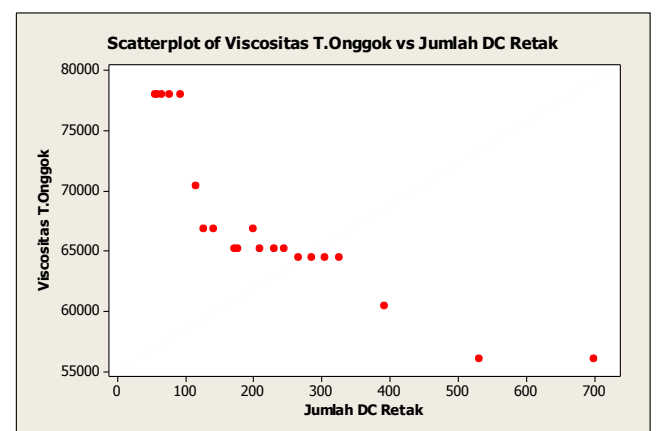

Gambar 4. Scatter Diagram untuk retak dengan Viskositas Tepung Onggok

Nilai korelasi antara kecacatan retak dengan viskositas tepung onggok adalah sebagai berikut:

$$
\begin{aligned}
& r=\frac{n \sum x y-\sum x \sum y}{\sqrt{\left.\left[n\left(\sum x^{2}\right)-\left(\sum x\right)^{2}\right] n\left(\sum y^{2}\right)-\left(\sum y\right)^{2}\right]}} \\
& r=\frac{21(206.790 .400)-(3.307)(1.363 .600)}{\left.\sqrt{\left[21(622.873)-(3.307)^{2}\left[21(89.234 .080 .000)-(1.363 .600)^{2}\right.\right.}\right]} \\
& r=-0,946
\end{aligned}
$$

Perhitungan diatas menunjukkan korelasi yang negatif kuat antarakecacatan terpotong dan retak dengan viskositas tepung onggok yang berarti kedua faktor kecacatan tersebut berbanding terbalik.

\section{F. Peta Kontrol}

Peta kontrol yang digunakan untuk menganalisa proporsi kecacatan adalah peta $\mathrm{p}$, karena peta $\mathrm{p}$ menggambarkan bagian yang ditolak karena tidak sesuai dengan spesifikasi yang diinginkan.

Peta kontrol $\mathrm{p}$ untuk jenis kecacatan terpotong dapat dilihat pada Gambar 5.

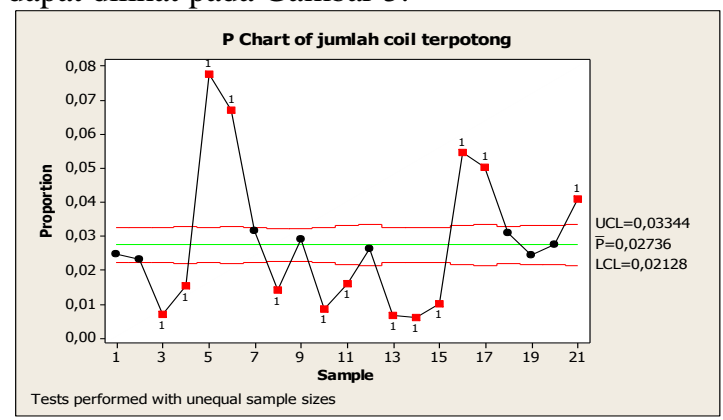

Gambar 5. Peta Kontrol Coil Terpotong 
Gambar 5. menunjukkan adanya beberapa data yang out of control sehingga perlu dilakukan revisi.Peta kontrol $p$ untuk jenis kecacatan terpotong revisi dapat dilihat pada Gambar 6.

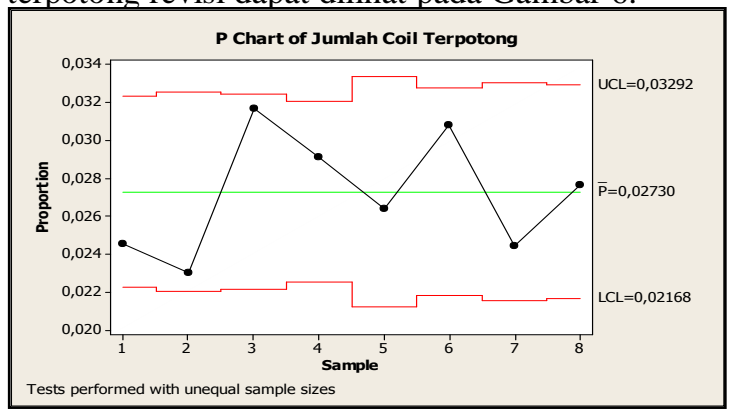

Gambar 6. Peta Kontrol Coil Terpotong Revisi

Gambar 6. menunjukkan bahwa tidak terdapat data yang out of control sehingga revisi selesai.

Peta kontrol $\mathrm{p}$ untuk jenis kecacatan retak dapat dilihat pada Gambar 7.

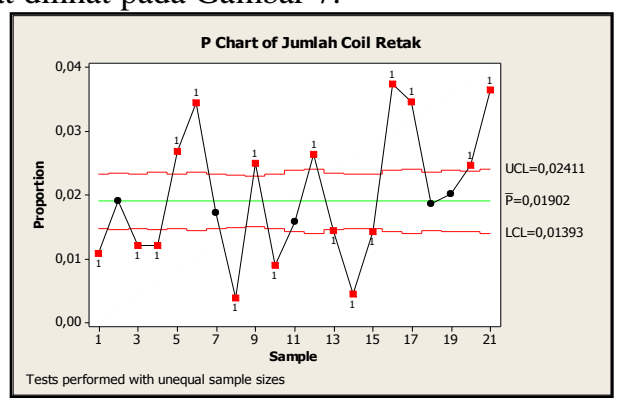

Gambar 7. Peta Kontrol Coil Retak

Gambar 7. menunjukkan adanya beberapa data yang out of control sehingga perlu dilakukan revisi.Peta kontrol $\mathrm{p}$ untuk jenis kecacatan retak revisi dapat dilihat pada Gambar 8 .

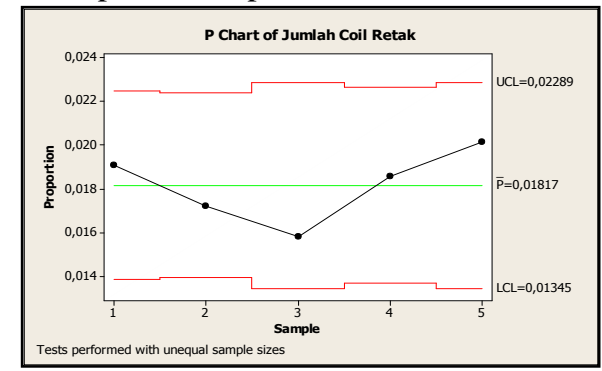

Gambar 8. Peta Kontrol Coil Terpotong Revisi Gambar 5.8. menunjukkan bahwa tidak terdapat data yang out of control sehingga revisi selesai.

\section{G) Diagram Sebab Akibat}

Penyebab masalah pada jenis kecacatan terpotong dapat diamati dengan menggunakan cause and effect diagram. Cause and effect diagramuntuk jenis kecacatan terpotong dan retak dapat dilihat pada Gambar 9. dan Gambar 10.

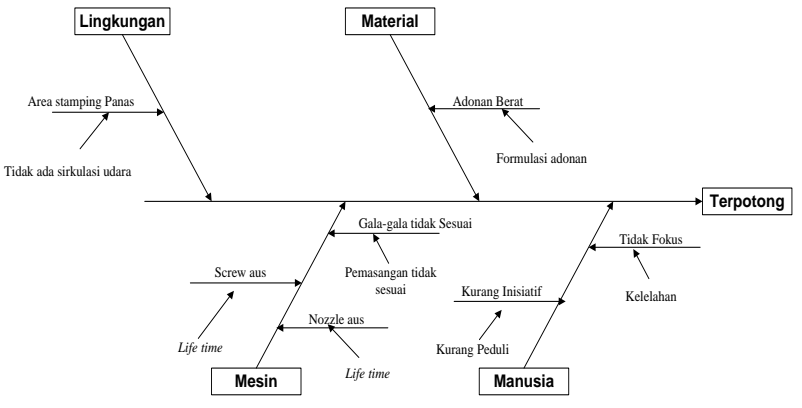
Gambar 9. Diagram Sebab Akibat Jenis
Kecacatan Terpotong

Ditinjau dari segi manusia, terdapat beberapa faktor yang dapat mempengaruhi terjadinya terpotongnya coil seperti: lalai, kurang peduli dan kurang personil.

Bahan yang masuk terkadang dalam kondisi lembek dan adonannya berat sehingga dapat menjadi faktor kecacatan produk.

Kondisi mesin kadang yang beberapa bagian mengalami kerusakan atau perlu penggantian spare part mesin, seperti: screw aus, nozzle aus dan galagala tidak sesuai.

Ditinjau dari segi lingkungan kerja, faktor yang menjadi penyebab terjadi kecacatan adalah area stamping panas sehingga mengganggu konsentrasi operator.

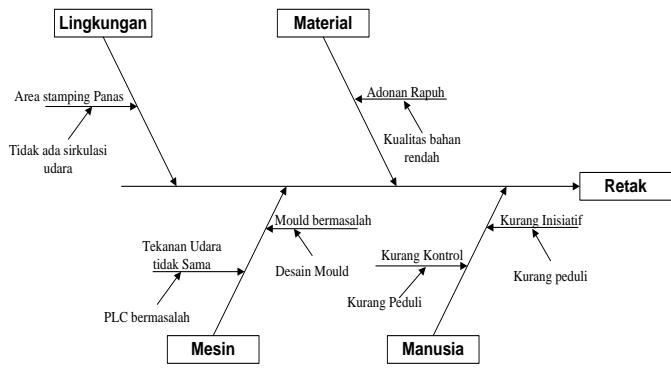

Gambar 10. Diagram Sebab Akibat Jenis Kecacatan Retak

Ditinjau dari segi manusia, terdapat beberapa faktor yang dapat mempengaruhi terjadinya terpotongnya coil seperti: kurang inisiatif, kurang kontrol terhadap mould.

Bahan yang masuk terkadang dalam kondisi kurang tepung dan adonannya rapuh sehingga dapat menjadi faktor kecacatan produk.

Kondisi mesin kadang yang beberapa bagian mengalami kerusakan atau perlu penggantian spare part mesin, seperti: Mould bermasalah dan tekanan udara tidak sama.

Ditinjau dari segi lingkungan kerja, faktor yang menjadi penyebab terjadi kecacatan adalah area stamping panas sehingga mengganggu konsentrasi operator. 
H) Failure Mode and Effect Analysis (FMEA)

Langkah selanjutnya adalah menentukan faktor-faktor yang berpengaruh terhadap kecacatan produk dengan mengidentifitasi potensi kegagalan yang akan timbul dengan menggunakan metode Failure Mode and Effect Analysis (FMEA) Hasil rekapitulasi untuk jenis kecacatan terpotong dan retak dapat di tabel RPN pada Tabel 5. dan Tabel 6.

Tabel 5. Rekapitulasi FMEA Terpotong

\begin{tabular}{|c|c|c|c|c|c|c|c|c|c|c|}
\hline \multirow{2}{*}{\multicolumn{2}{|c|}{$\begin{array}{l}\text { Part/Process } \\
\text { Function\& } \\
\text { specification }\end{array}$}} & \multirow{3}{*}{$\begin{array}{c}\begin{array}{c}\text { Potensial } \\
\text { failure } \\
\text { mode }\end{array} \\
\\
\text { Speed } \\
\text { Tidak } \\
\text { Terkontrol } \\
\end{array}$} & \multirow{3}{*}{$\begin{array}{c}\text { Potensi } \\
\text { al effect } \\
\text { of } \\
\text { failure } \\
\\
\text { Sheet } \\
\text { Pendek }\end{array}$} & \multirow{2}{*}{\multicolumn{2}{|c|}{$\begin{array}{cc} & \text { Potensia } \\
S & l \\
\boldsymbol{S} & \text { Causes/ } \\
v & \text { Mechan } \\
& \text { isme } \\
& \text { failure }\end{array}$}} & \multirow{2}{*}{$\begin{array}{l}O \\
c \\
c\end{array}$} & \multicolumn{2}{|c|}{ Current Controls Design } & \multirow{2}{*}{$\begin{array}{l}D \\
e \\
t\end{array}$} & \multirow{2}{*}{$\begin{array}{l}R \\
P \\
N\end{array}$} \\
\hline & & & & & & & Prevention & Detection & & \\
\hline \multirow{2}{*}{$\begin{array}{c}\text { Manusi } \\
\mathbf{a}\end{array}$} & $\begin{array}{l}\text { Tidak } \\
\text { Fokus }\end{array}$ & & & 7 & $\begin{array}{c}\text { Kelalaha } \\
\mathrm{n}\end{array}$ & 4 & $\begin{array}{c}\text { Melakukan } \\
\text { Rotasi } \\
\text { Pekerja } \\
\end{array}$ & $\begin{array}{c}\text { Melakukan } \\
\text { Refresh } \\
\text { Training }\end{array}$ & 6 & 168 \\
\hline & $\begin{array}{l}\text { Kurang } \\
\text { inisiatif }\end{array}$ & $\begin{array}{c}\text { Mesin Cepat } \\
\text { aus }\end{array}$ & $\begin{array}{l}\text { Sheet } \\
\text { rusak }\end{array}$ & 8 & $\begin{array}{l}\text { Kurang } \\
\text { peduli }\end{array}$ & 5 & $\begin{array}{l}\text { Melakukan } \\
\text { pengawasan }\end{array}$ & $\begin{array}{c}\text { Melakukan } \\
\text { Refresh } \\
\text { Training }\end{array}$ & 6 & 240 \\
\hline $\begin{array}{l}\text { Materi } \\
\quad \text { al }\end{array}$ & $\begin{array}{c}\text { Adonan } \\
\text { Berat }\end{array}$ & $\begin{array}{c}\text { Sheet } \\
\text { pendek }\end{array}$ & $\begin{array}{l}\text { Banyak } \\
\text { recyle }\end{array}$ & 5 & $\begin{array}{c}\text { Terlalu } \\
\text { banyak } \\
\text { air }\end{array}$ & 4 & $\begin{array}{c}\text { Pemeriksaan } \\
\text { adonan }\end{array}$ & $\begin{array}{l}\text { Penyesuaian } \\
\text { formulasi }\end{array}$ & 5 & 100 \\
\hline \multirow{3}{*}{ Mesin } & $\begin{array}{l}\text { Gala-gala } \\
\text { tidak } \\
\text { sesuai }\end{array}$ & $\begin{array}{l}\text { Sheet tidak } \\
\text { sesuai }\end{array}$ & $\begin{array}{c}\text { Banyak } \\
\text { sheet } \\
\text { cacat }\end{array}$ & 6 & $\begin{array}{c}\text { Pemasan } \\
\text { gan } \\
\text { tidak } \\
\text { sesuai }\end{array}$ & 5 & $\begin{array}{c}\text { Pemeriksaan } \\
\text { center } \\
\text { laning }\end{array}$ & $\begin{array}{c}\text { Menyesuaikan } \\
\text { gala-gala }\end{array}$ & 4 & 120 \\
\hline & Screw aus & $\begin{array}{c}\text { Adonan } \\
\text { tidak keluar }\end{array}$ & $\begin{array}{l}\text { Tidak } \\
\text { ada } \\
\text { sheet }\end{array}$ & 5 & $\begin{array}{c}\text { Usia } \\
\text { pakai } \\
\text { terlalu } \\
\text { lama }\end{array}$ & 4 & $\begin{array}{c}\text { Diperiksa } \\
\text { secara } \\
\text { berkala }\end{array}$ & $\begin{array}{c}\text { Penggatian } \\
\text { screw }\end{array}$ & 4 & 80 \\
\hline & Nozzle aus & $\begin{array}{l}\text { Pinggiran } \\
\text { Sheet } \\
\text { banyak } \\
\text { cacat }\end{array}$ & $\begin{array}{c}\text { Sheet } \\
\text { tidak } \\
\text { sempurn } \\
\text { a }\end{array}$ & 5 & $\begin{array}{c}\text { Usia } \\
\text { pakai } \\
\text { terlalu } \\
\text { lama }\end{array}$ & 4 & $\begin{array}{c}\text { Diperiksa } \\
\text { secara } \\
\text { berkala }\end{array}$ & $\begin{array}{c}\text { Penggatian } \\
\text { nozzle }\end{array}$ & 4 & 80 \\
\hline $\begin{array}{c}\text { Lingku } \\
\text { ngan }\end{array}$ & $\begin{array}{c}\text { Area } \\
\text { stamping } \\
\text { panas }\end{array}$ & $\begin{array}{l}\text { Operator } \\
\text { cepat lelah }\end{array}$ & $\begin{array}{c}\text { Bekerja } \\
\text { menjadi } \\
\text { lalai }\end{array}$ & 3 & $\begin{array}{l}\text { Kurang } \\
\text { sirkulasi }\end{array}$ & 2 & $\begin{array}{c}\text { Exhaust } \\
\text { oven }\end{array}$ & $\begin{array}{c}\text { Menambah } \\
\text { exhaust oven }\end{array}$ & 2 & 12 \\
\hline
\end{tabular}

Tabel 6. Rekapitulasi FMEA Retak

\begin{tabular}{|c|c|c|c|c|c|c|c|c|c|c|}
\hline \multirow{2}{*}{\multicolumn{2}{|c|}{$\begin{array}{l}\text { Part/Process } \\
\text { Function\& } \\
\text { specification }\end{array}$}} & \multirow{2}{*}{$\begin{array}{l}\text { Potensial } \\
\text { failure } \\
\text { mode }\end{array}$} & \multirow{2}{*}{$\begin{array}{c}\text { Potensial effect } \\
\text { of failure }\end{array}$} & \multirow{2}{*}{\multicolumn{2}{|c|}{$\begin{array}{cc} & \text { Potensial } \\
S & \text { Causes/ } \\
e & \text { Mechanis } \\
v & \text { me } \\
& \text { failure }\end{array}$}} & \multirow{2}{*}{$\begin{array}{l}O \\
c \\
c\end{array}$} & \multicolumn{2}{|c|}{ Current Controls Design } & \multirow{2}{*}{$\begin{array}{l}D \\
e \\
t\end{array}$} & \multirow{2}{*}{$\begin{array}{l}\boldsymbol{R} \\
\boldsymbol{P} \\
\boldsymbol{N}\end{array}$} \\
\hline & & & & & & & Prevention & Detection & & \\
\hline \multirow[t]{2}{*}{$\begin{array}{l}\text { Manusi } \\
\quad \mathbf{a}\end{array}$} & $\begin{array}{l}\text { Kurang } \\
\text { inisiatif }\end{array}$ & $\begin{array}{c}\text { Mesin cepat } \\
\text { aus }\end{array}$ & Sheet rusak & 6 & $\begin{array}{l}\text { Kurang } \\
\text { peduli }\end{array}$ & 3 & $\begin{array}{c}\text { Melakukan } \\
\text { Rotasi } \\
\text { Pekerja }\end{array}$ & $\begin{array}{c}\text { Melakukan } \\
\text { Refresh } \\
\text { Training }\end{array}$ & 7 & 126 \\
\hline & $\begin{array}{l}\text { Kurang } \\
\text { kontrol }\end{array}$ & $\begin{array}{c}\text { Proses tidak } \\
\text { berjalah } \\
\text { baik }\end{array}$ & $\begin{array}{c}\text { Banyak coil } \\
\text { cacat }\end{array}$ & 7 & $\begin{array}{l}\text { Kurang } \\
\text { peduli }\end{array}$ & 3 & $\begin{array}{c}\text { Pengawasan } \\
\text { leader }\end{array}$ & $\begin{array}{c}\text { Mengawasi } \\
\text { kinerja } \\
\text { operator }\end{array}$ & 6 & 126 \\
\hline $\begin{array}{c}\text { Materia } \\
\mathbf{l}\end{array}$ & $\begin{array}{l}\text { Adonan } \\
\text { Rapuh }\end{array}$ & $\begin{array}{l}\text { Permukaaan } \\
\text { coil rusak }\end{array}$ & $\begin{array}{c}\text { Coil tidak } \\
\text { tercetak } \\
\text { sempurna }\end{array}$ & 5 & $\begin{array}{l}\text { Tepung } \\
\text { kurang } \\
\text { masak }\end{array}$ & 8 & $\begin{array}{c}\text { Pemeriksaa } \\
\text { n kualitas } \\
\text { bahan }\end{array}$ & $\begin{array}{c}\text { Penyesuaian } \\
\text { ulang } \\
\text { formulasi }\end{array}$ & 4 & 160 \\
\hline Mesin & $\begin{array}{c}\text { Mould } \\
\text { bermasala } \\
\mathrm{h}\end{array}$ & $\begin{array}{l}\text { Coil mudah } \\
\text { rusak }\end{array}$ & $\begin{array}{l}\text { Coil tidak } \\
\text { tercetak } \\
\text { sempurna }\end{array}$ & 8 & $\begin{array}{l}\text { Pemasang } \\
\text { an mould } \\
\text { tidak } \\
\text { sesuai }\end{array}$ & 8 & $\begin{array}{c}\text { Pengawasan } \\
\text { desain } \\
\text { mould }\end{array}$ & $\begin{array}{l}\text { Change } \\
\text { mould }\end{array}$ & 4 & 256 \\
\hline
\end{tabular}


Tabel 6. Rekapitulasi FMEA Retak (Lanjutan)

\begin{tabular}{|c|c|c|c|c|c|c|c|c|c|c|}
\hline \multirow{2}{*}{\multicolumn{2}{|c|}{$\begin{array}{l}\text { Part/Process } \\
\text { Functiond } \\
\text { specification }\end{array}$}} & \multirow{2}{*}{$\begin{array}{l}\text { Potensial } \\
\text { failure } \\
\text { mode }\end{array}$} & \multirow{2}{*}{$\begin{array}{c}\text { Potensial effect } \\
\text { of failure }\end{array}$} & \multirow{2}{*}{\multicolumn{2}{|c|}{$\begin{array}{cc} & \text { Potensial } \\
\boldsymbol{S} & \text { Causes/ } \\
\boldsymbol{e} & \text { Mechanis } \\
\boldsymbol{v} & \text { me } \\
& \text { failure }\end{array}$}} & \multirow{2}{*}{$\begin{array}{l}O \\
c \\
c\end{array}$} & \multicolumn{2}{|c|}{ Current Controls Design } & \multirow{2}{*}{$\begin{array}{l}D \\
e \\
t\end{array}$} & \multirow{2}{*}{$\begin{array}{l}\boldsymbol{R} \\
\boldsymbol{P} \\
\boldsymbol{N}\end{array}$} \\
\hline & & & & & & & Prevention & Detection & & \\
\hline & $\begin{array}{c}\text { Tekanan } \\
\text { udara } \\
\text { tidak } \\
\text { sama }\end{array}$ & $\begin{array}{l}\text { Coil mudah } \\
\text { rusak }\end{array}$ & $\begin{array}{l}\text { Coil tidak } \\
\text { tercetak } \\
\text { sempurna }\end{array}$ & 7 & $\begin{array}{c}\text { Pengatura } \\
\text { n PLC } \\
\text { tidak } \\
\text { sesuai }\end{array}$ & 8 & $\begin{array}{c}\text { Pengawasan } \\
\text { terhadap } \\
\text { PLC }\end{array}$ & $\begin{array}{c}\text { Change } \\
\text { PLC }\end{array}$ & 4 & 224 \\
\hline $\begin{array}{l}\text { Lingku } \\
\text { ngan }\end{array}$ & $\begin{array}{c}\text { Area } \\
\text { stamping } \\
\text { panas }\end{array}$ & $\begin{array}{l}\text { Operator } \\
\text { tidak fokus }\end{array}$ & $\begin{array}{c}\text { Bekerja } \\
\text { menjadi lalai }\end{array}$ & 9 & $\begin{array}{l}\text { Kurang } \\
\text { sirkulasi }\end{array}$ & 2 & $\begin{array}{c}\text { Exhaust } \\
\text { oven }\end{array}$ & $\begin{array}{c}\text { Menambah } \\
\text { exhaust } \\
\text { oven }\end{array}$ & 2 & 36 \\
\hline
\end{tabular}

Jenis kecacatan terpotong yang memilik potensi terbesar adalah kurang inisiatif dengan nilai RPN sebesar 240. Nilai tersebut menunjukkan faktor penyebab terbesar untuk kecacatan terpotong adalah faktor manusia, kurang inisiatif dan faktor penyebabnya ialah kurang peduli.

Jenis kecacatan retak yang memilik potensi terbesar adalah mould bermasalah dengan nilai RPN sebesar 256. Nilai tersebut menunjukkan faktor penyebab terbesar untuk kecacatan terpotong adalah mesin, mould bermasalah, faktor peyebabnya terjadinya adalah pemasangan mould yang tidak sesuai.

\section{KESIMPULAN}

Kesimpulan yang diperoleh dari penelitian tersebut adalah sebagai berikut:

1. Terdapat tiga jenis kecacatan yang paling dominan pada coil basah di PT. XYZ yaitu terpotong, retak dan renggang.

2. Jenis kecacatan tertinggi adalah terpotong sebanyak 4.757 double coil kemudian retak sebanyak 3.307 double coil dan renggang sebanyak 2.375 double coil.

3. Frekuensi penyebab kecacatan yang paling tinggi untuk terpotong adalah dari faktor manusia, yaitu tidak fokus dan kurang inisiatif dengan nilai RPN 240. Sedangkan untuk retak adalah mesin, yaitu mould bermasalah dan tekanan udara tidak sama dengan nilai RPN 256.

4. Penyebab kecacatan untuk terpotong disebabkan oleh kurang inisiatif operator. Sedangkan untuk retak disebabkan oleh mould yang bermasalah

\section{DAFTAR PUSTAKA}

Besterfield, Dale H. 1998. "Quality Control". United States of America: PrenticeHall International

Engineering Corporation, Dyadem. 2003. "Guidelines for Failure Mode and Effect Analysis, For Automotive, Aerospace and General Manufacturing Industrie
Nasution, M.N. 2005."Manajemen Mutu Terpadu”. Bogor :Ghalia Indonesia 